\title{
Primary Human Neutrophils Exhibit a Unique HIV-Directed Antibody-Dependent Phagocytosis Profile
}

\author{
Rebecca L.R. Powell Alisa Fox Vincenza Itri Susan Zolla-Pazner \\ Department of Infectious Diseases, Icahn School of Medicine at Mount Sinai, New York, NY, USA
}

\section{Keywords}

AIDS · Antibodies · Neutrophils · Phagocytosis · Viral infection

\begin{abstract}
The only clinical HIV vaccine trial to demonstrate efficacy, RV144, correlated protection with the antibodies (Abs) mediating function via the "constant" immunoglobulin region, the crystallizable fragment (Fc). These data have supported a focus on the induction of Abs by vaccines that trigger antiviral activities by relevant leukocytes via Fc receptors (FcRs). Neutrophils are phagocytes that comprise $>50 \%$ of leukocytes and display unique FcRs. We sought to compare the Ab-dependent cellular phagocytosis (ADCP) activity of human neutrophils to the commonly assayed THP-1 cell line. HIV-specific Abs were employed to elicit ADCP of beads coated with HIV envelope protein. Overall, trends were noted among neutrophil donors and the ADCP profile was different from that of THP-1 cells. mAb ELISA titers correlated with ADCP by THP-1 cells but not neutrophils. Monoclonal (m)Abs were also tested with primary monocytes. Donor-todonor variation was high, and hindered the analysis of this dataset, but it was, in itself, an important finding. This study illustrates the concept that the assessment of FcR-mediated $\mathrm{Ab}$ activity with a frequently used cell line such as THP-1 is not necessarily indicative of relevant $A b$ functionality in vivo,
\end{abstract}

\begin{tabular}{ll}
\hline KARGER & ( 2018 The Author(s) \\
& Published by S. Karger AG, Basel Oparger \\
E-Mail karger@karger.com & This article is licensed under the Creative Commons Attribution- \\
www.karger.com/jin & NonCommercial-NoDerivatives 4.0 International License (CC BY- \\
NC-ND) (http://www.karger.com/Services/OpenAccessLicense). \\
Usage and distribution for commercial purposes as well as any dis- \\
tribution of modified material requires written permission.
\end{tabular}

and this calls for in-depth study of the properties of the HIV antibodies best-suited to eliciting antiviral activities by primary cells.

(C) 2018 The Author(s)

Published by S. Karger AG, Basel

\section{Background}

The only clinical HIV vaccine trial to date to show significant efficacy (RV144) found that reduced infection rates correlated with the level of nonneutralizing antibodies (Abs) specific for the V2 region of the gp120 envelope (Env) glycoprotein [1]. Follow-up analyses of the RV144 data found that the antiviral activities mediated by the "constant" region of the immunoglobulin molecule, crystallizable fragment $(\mathrm{Fc})$, including Ab-dependent cellular cytotoxicity and phagocytosis (ADCC and ADCP), correlated with the level of serum V2 Abs $[2,3]$. This is consistent with previous studies implicating Fc-mediated Ab activities in responses to various pathogens [4-6]. Fc receptors (FcRs) are found on virtually all innate immune cells and are a critical link between the Abs elicited by the adaptive immune response and Fc-mediated innate immune functions [7]. Signals generated by and activities elicited by a given $\mathrm{FcR}$ are determined by both $\mathrm{Ab}$ isotype and FcR subclass, with each FcR eliciting divergent signals [8]. 
It is critical that we turn our focus to designing a vaccine capable of eliciting highly functional Abs that can trigger relevant leukocytes via FcRs to destroy a virus, kill infected cells, and restrict viral spread. In humans, neutrophils comprise $>50 \%$ of leukocytes in the blood and are key gatekeepers that can rapidly phagocytose pathogens [9]. The key protective functions of human neutrophils are mediated by a unique repertoire of $\mathrm{FcRs}$ that act by means of highly specialized coordinated mechanisms. These essential gatekeepers are numerous and active, not only in the blood but in the mucosal tissues relevant to the transmission of HIV [9]. Neutrophils are a critical first line of defense against essentially all pathogens, likely including HIV, although this has been poorly studied. Indeed, analysis of the influence of neutropenia on HIV-1 susceptibility has shown an approximately 3 -fold-increased risk of HIV-1 acquisition [10], and in studies of neutrophils in HIV-infected mothers and their newborns, the neutrophil counts of infected infants were significantly lower than those of uninfected infants, with every 1,000 -cell $/ \mu \mathrm{L}$ increase being associated with an $11 \%$ reduction in infection risk [11].

Human neutrophils express Fc $\gamma$ RIIa (CD32a), an activating $\mathrm{FcR}$ with typical transmembrane and intracellular signaling domains, and Fc $\gamma$ RIIIb (CD16b), which lacks an intracellular signaling domain but has been shown to trigger numerous pathogen-killing functions, including ADCP [12-14]. Activated neutrophils have also been shown to express Fc $\gamma$ RI (CD64); however, activated neutrophils appear "exhausted" and cannot perform ADCP via this receptor $[9,13,15]$. In contrast, the THP-1 human monocyte cell line, the most commonly-used cell line for $\mathrm{ADCP}$ assays, possesses a completely different $\mathrm{Fc} \gamma \mathrm{R}$ profile that includes high levels of Fc $\gamma$ RI, Fc $\gamma$ RIIa/b, and Fc $\gamma$ RIIIa $[16,17]$. The neutrophil FcR profile makes this cell type unique among those that mediate Fc-dependent $\mathrm{Ab}$ activities, and it is thus essential to study HIV $\mathrm{Ab}$ function in the context of primary human neutrophils to truly understand their relevant functions in preventing infection and/or controlling viral spread upon infection, as has been elucidated for other viral pathogens [18-20].

In this study, we sought to examine if there were differences in the ADCP activity of THP-1 cells and primary human neutrophils, as would be predicted by their highly unique FcR profiles $[9,12-17]$. Primary monocyte and THP-1 cell ADCP activity was also compared, given that these cells have been shown to display more similar Fc $\gamma \mathrm{R}$ profiles [17]. A panel of mAbs specific for HIV Env was employed to elicit ADCP of fluorescent beads coated with Env gp120, and ADCP scores were calculated for each cell type and compared. Differences in activity were evident, indicating a need to move away from the cell-line model for studying Fc-mediated activity by HIV-specific Abs, and potentially by Abs elicited by various HIV immunization protocols as well as by immunization and infection by other pathogens.

\section{Materials and Methods}

\section{Antibodies}

The mAbs used here were originally isolated in our lab from peripheral blood mononuclear cells (PBMCs) of HIV-1-infected individuals, using cellular (hybridoma) techniques described previously. The mAbs used in this study were re-expressed using recombinant technology as $\operatorname{IgG}_{1}$ [21-27]. Monoclonal Abs 1357 [28], 1361 [28], 2158 [29], and 830A [26] are specific for the V2i epitope of gp120 as defined in Spurrier et al. [30]. Monoclonal Abs 2219 [28], 2557 [31], and 3792 [32] are specific for the V3 loop of gp120. Recombinant mAbs were produced by conventional molecular techniques as previously described [33] in 293T cells. mAbs were used only if they passed all QC assays as previously described [34].

\section{Primary Human Neutrophils and Monocytes}

These cells were obtained from healthy HIV-uninfected volunteers. Note that different donors were used for the neutrophil and monocyte experiments. Each participant was recruited and interviewed in accordance with ethics and institutional review board (IRB) approval under the guidance and authorization of the Mount Sinai School of Medicine's Program for the Protection of Human Subjects (PPHS) using an IRB-approved protocol for venipuncture. Health Information Privacy and Portability Act (HIPPA) regulations and best practice guidelines for biospecimen management were followed. Cells were purified using a standard protocol [35]. Briefly, at room temperature, $25 \mathrm{~mL}$ of neutrophil isolation media (Lympholyte-Poly, Cedarlane) was aliquoted to the bottom of a $50-\mathrm{mL}$ centrifuge tube. Twenty-five $\mathrm{mL}$ of whole blood was laid carefully over the separation media. The tubes were centrifuged at $500 \mathrm{~g}$ for $35 \mathrm{~min}$ at $22^{\circ} \mathrm{C}$. Monocyte or neutrophil layers were collected into a clean centrifuge tube, diluted with $50 \mathrm{~mL}$ Hank's balanced salt solution (HBSS) without $\mathrm{Ca}^{2+} / \mathrm{Mg}^{2+}$, and centrifuged at $350 \mathrm{~g}$ for $10 \mathrm{~min}$. Supernatant was discarded, and erythrocytes were lysed with $10 \mathrm{~mL}$ red cell lysis buffer (Life Technologies). Care was taken to gently resuspend pellets to avoid neutrophil activation and death. Tubes were centrifuged at $250 \mathrm{~g}$ for $5 \mathrm{~min}$ and the supernatant discarded. The pellet was washed with $50 \mathrm{~mL}$ HBSS, the centrifugation repeated, and the pellet then resuspended in $5 \mathrm{~mL}$ of HBSS and counted by automated cell counter (Life Technologies). Cells were used immediately.

\section{ADCP Target Beads}

Commercially available Env gp120 protein from the Clade C strain ZM53 (Immunetech), was biotinylated using the EZ-Link ${ }^{\mathrm{TM}}$ NHS-LC-LC-Biotin kit (ThermoFisher) according to the manufacturer's protocol. Protein was conjugated to $1 \mu \mathrm{m}$ FluoSpheres ${ }^{\circledR}$ NeutrAvidin ${ }^{\circledR}$-labeled microspheres (ThermoFisher) at $20 \mu \mathrm{g}$ protein $/ 12 \mu \mathrm{L}$ stock beads for $2 \mathrm{~h}$ at $37^{\circ} \mathrm{C}$ according to the manufacturer's instructions. 


\section{Measurement of ADCP}

The ADCP assay was adapted from Ackerman et al. [16]. $10 \mu \mathrm{L}$ of bead solution was aliquoted per well in round-bottomed 96-well plates. Five-fold dilutions of each $\mathrm{mAb}$ in HBSS (including a negative control, anti-anthrax PA mAb 3865) was added and incubated for $2 \mathrm{~h}$ at $37^{\circ} \mathrm{C}$. Two hundred microliters of HBSS was added to wells, the plates were centrifuged at 2,000 $\mathrm{g}$ for $10 \mathrm{~min}$, and the supernatant was carefully removed to avoid disturbing the bead pellet. Twenty-five thousand THP- 1 cells (ATCC) or $2 \times 10^{5}$ freshly isolated neutrophils or monocytes were added and incubated overnight (THP-1) or for $2 \mathrm{~h}$ (neutrophils/monocytes) at $37^{\circ} \mathrm{C}$. For certain control experiments, $10 \mu \mathrm{g} / \mathrm{mL}$ of the actin inhibitor cytochalasin D (CytoD, Sigma), $50 \mu \mathrm{g} / \mathrm{mL}$ of the FcRblocking agent FcBlock (BD), or a combination of both was preincubated with cells prior to their addition to the plates. The plates were centrifuged, washed twice, stained with viability dye (BD) in PBS according to the manufacturer's instructions, fixed in $0.5 \%$ formaldehyde, and then analyzed by flow cytometry on an LSR Fortessa. ADCP was measured on the FITC channel as percentage of bead-positive cells of appropriate SSC/FSC after initial gating to eliminate doublets, debris, and dead cells. Phagocytic scores were calculated as: (\% bead-positive cells $\times$ MFI of positive population) $/ 10^{5}$. Calculated ADCP scores were normalized by subtracting the score from the negative-control mAb tested simultaneously. If the control $\mathrm{mAbs}$ elicited $>3$ times the standard deviation of normal (determined from pilot experiments with 3 donors), the data were excluded. ADCP scores at each $\mathrm{mAb}$ dilution were used to determine the area under the curve (AUC) in GraphPad Prism. Statistics were performed in GraphPad Prism. Comparisons of mean ADCP AUC values were performed by one-way ANOVA (Tukey's multiple comparisons test with single pooled variance) or by the unpaired two-tailed Student $t$ test (for $n \geq 8$ ) or Mann-Whitney $U$ test (for $n<8)(95 \%$ confidence intervals). ELISA and ADCP scores were compared by the Pearson correlation, using a onetailed $p$ value ( $95 \%$ confidence interval).

ELISA

Assay was performed as previously described using gp $120_{\text {ZM53 }}$ protein (Immune Technology) [36].

\section{Results}

\section{Neutrophil ADCP Is Strongly Elicited by V3 mAbs}

As part of the development of the neutrophil ADCP assay, we confirmed that, as shown previously for the classical THP-1 assay, neutrophil ADCP cannot occur without actin polymerization/depolymerization and/or accessible FcRs [16]. This was determined by titering the $\mathrm{V} 2 \mathrm{i}$-specific $\mathrm{mAb} 830 \mathrm{~A}$ which was used to form immune complexes with target gp120-conjugated fluorescent beads. Freshly isolated neutrophils were incubated with the actin inhibitor CytoD and/or a cocktail of FcR-blocking $\mathrm{Abs}$ ( $\mathrm{FcBlock}$ ) for $30 \mathrm{~min}$ prior to their exposure to the immune complexes. While untreated neutrophils fluoresced, reflecting bead uptake, cells that had been pre-

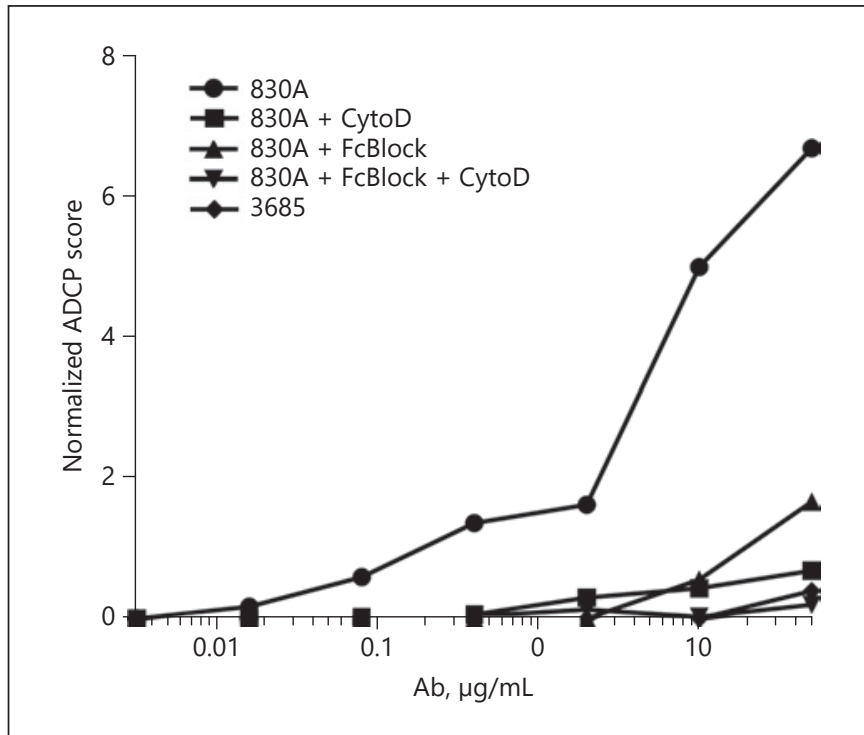

Fig. 1. Neutrophil ADCP requires actin polymerization/depolymerization and accessible FcRs. The V2i-specific mAb 830A and the anti-anthrax PA mAb 3865 were titrated and used to form immune complexes with target gp120-conjugated fluorescent beads. Freshly isolated human blood neutrophils were incubated with the actin inhibitor cytochalasin D (CytoD) and/or a cocktail of FcRblocking Abs (FcBlock), or media alone, for 30 min prior to their exposure to the immune complexes. ADCP was measured on the FITC channel as percentage of bead-positive cells after initial FSC/ SSC and viability stain gating to eliminate doublets, debris, and dead cells. Phagocytic scores were calculated as: (\% bead-positive cells $\times$ MFI of positive population) $/ 10^{5}$. ADCP scores were normalized by subtracting the "no $\mathrm{mAb}$ " control score. Data are representative of 3 separate experiments.

incubated with CytoD or FcBlock prior to addition of the 830A-bead complexes exhibited a significant 5 - to 10 -fold reduction in ADCP score, and this effect appeared to be synergistic when both compounds were added to the cells prior to the ADCP assay (Fig. 1). Follow-up experiments included CytoD/FcBlock controls to ensure cell fluorescence was indicative of bead internalization (data not shown).

To account for the genetic variability of human FcRs and other proteins involved in phagocytosis, 5 different blood donors were used for neutrophil isolation and ADCP experiments [37, 38]. The ADCP assay was largely performed as described for THP-1 cells, but the overnight incubation was shortened to $2 \mathrm{~h}$ since neutrophils are short-lived and prone to overactivation and exhaustion [9]. ADCP of gp120-coated beads was tested with the $\mathrm{IgG}_{1} \mathrm{~V} 2 \mathrm{i}$-specific $\mathrm{mAbs} 1357,1361,2158$, and $830 \mathrm{~A}$, and the $\mathrm{IgG}_{1}$ V3-specific mAbs 2219, 2557, and 3792, as well 


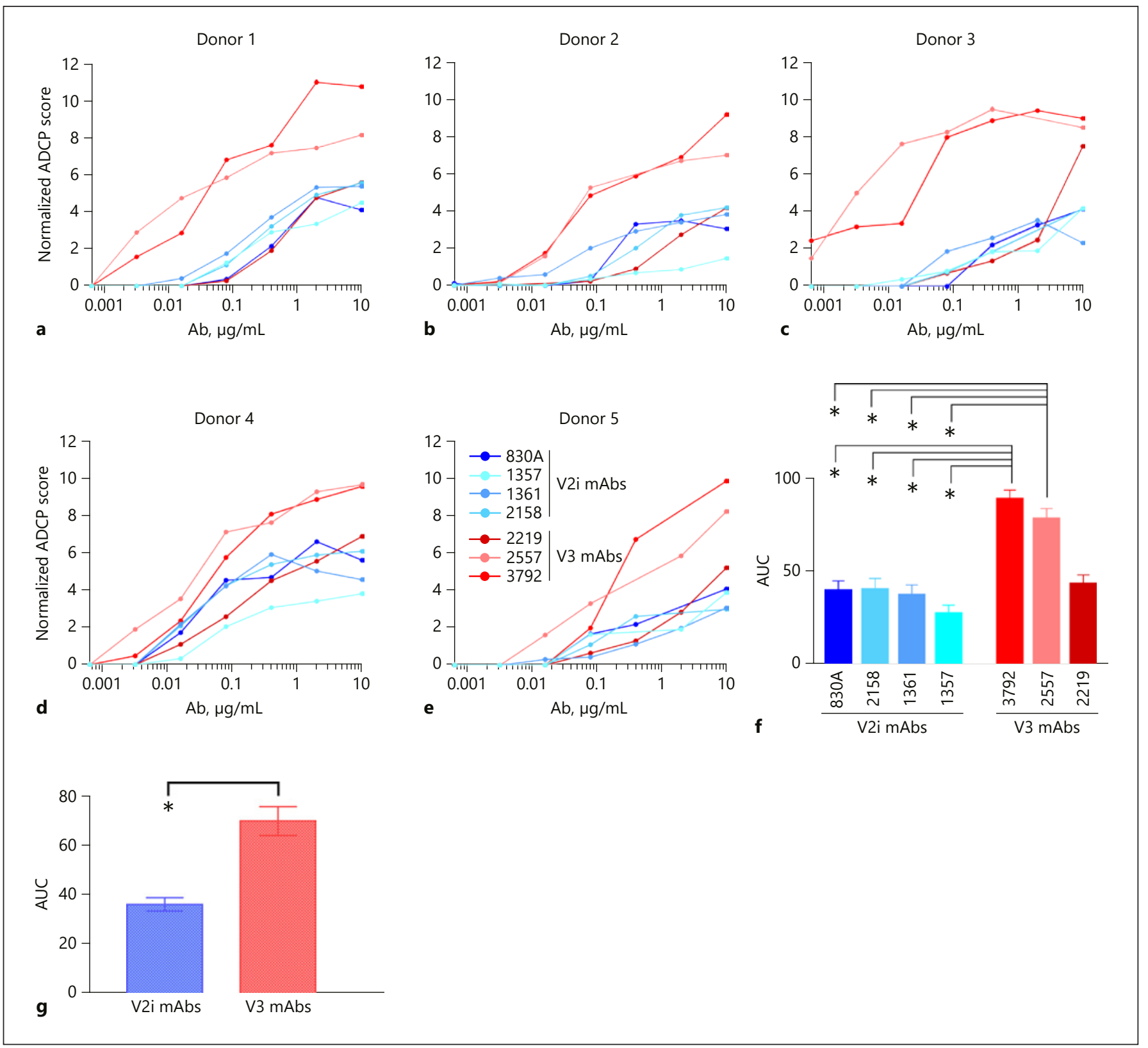

Fig. 2. Neutrophil ADCP is relatively consistent among donors and is strongly elicited by V3 mAbs. a-e ADCP profile of neutrophils obtained from 5 different donors. Abs were titrated and incubated with gp 120 beads for $2 \mathrm{~h}$ at $37^{\circ} \mathrm{C}$. Freshly isolated neutrophils were added and incubated for $2 \mathrm{~h}$ at $37^{\circ} \mathrm{C}$. ADCP scores were calculated and normalized by subtracting the scores from the neg-

as the negative control, anti-anthrax PA mAb 3865. As shown in Figure 2, neutrophils from each of the 5 donors exhibited a unique ADCP profile, although trends were displayed in the results from all the donors in the pattern of the relative potency of different mAbs in mediating ative-control $\mathrm{mAb}$ tested simultaneously. $\mathbf{f} \mathrm{ADCP}$ scores at each $\mathrm{mAb}$ dilution were used to determine area under the curve (AUC). Mean AUC values and SEM for the 5 donors are shown $(n=5)$. g Mean ADCP activity elicited in neutrophils by the mAbs tested, grouped by specificity $(n=15$ or 20$){ }^{*} p<0.05$.

ADCP. All donors exhibited the highest neutrophil ADCP elicited by V3 mAbs 3792 and 2557 (Fig. 2), while the remaining $6 \mathrm{mAbs}$ elicited lower levels of activity. AUC values for 3792 and 2557 (AUC $=89$ and 78, respectively) were 2- to 3-fold higher than those calculated for the re- 


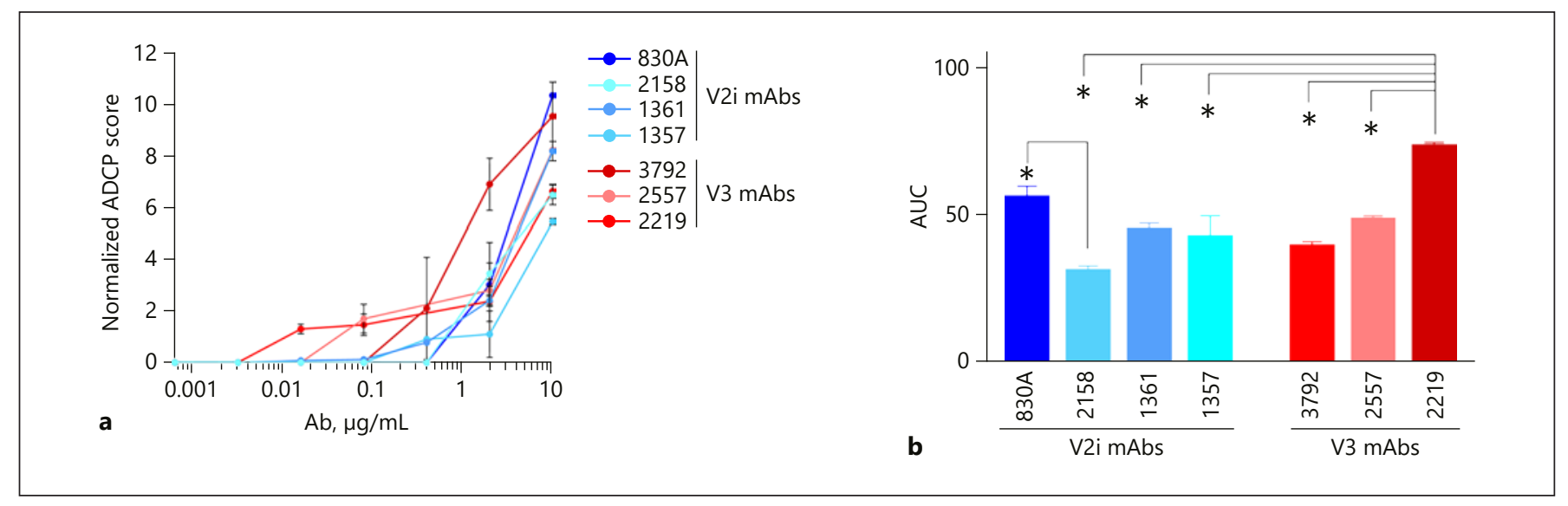

Fig. 3. ADCP profile of mAbs tested in the THP-1 assay is different from that of neutrophils. a mAbs were titrated and ADCP assay was performed as described above, with an overnight incubation of THP-1 cells and immune complexes $(n=3)$. b AUC values were calculated as above $(n=3) .{ }^{*} p<0.05$.

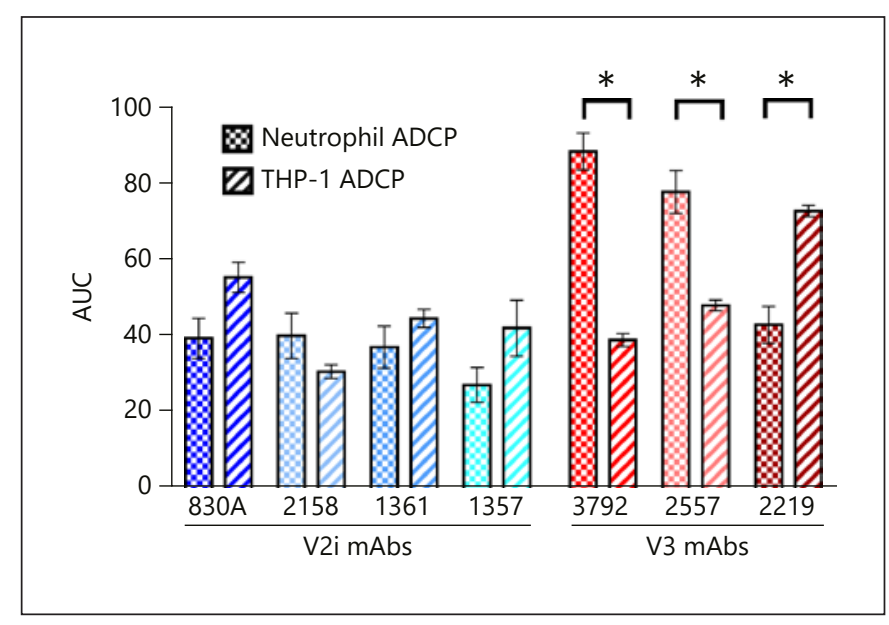

Fig. 4. Comparison of ADCP scores between the neutrophil and THP-1 cell assays highlight the unique profiles. ADCP assays were performed and scores calculated as described above. a Mean AUC values with SEM are shown for each $\mathrm{mAb}(n=3$ or 5$) .{ }^{*} p<0.05$.

maining 6 mAbs (AUC $=27-43)$. Mean ADCP scores were compared within the neutrophil dataset. There were highly statistically significant differences in mean ADCP activities for each $\mathrm{mAb}$, as determined by one-way ANOVA $\left(F_{6,28}=19.49, p \leq 0.0001\right)$. It was found that significant differences in ADCP potency clustered with the V3 mAbs (Fig. 2f), with 2557 and 3792 exhibiting significantly higher ADCP than all V2i mAbs. V3 mAb 2219 exhibited significantly lower activity than the other V3 mAbs. No significant differences were observed among the V2i

Neutrophils Exhibit a Unique HIV-Directed ADCP Profile
mAbs. When ADCP scores were grouped by specificity and $\mathrm{V} 2 \mathrm{i}$ versus $\mathrm{V} 3 \mathrm{ADCP}$ potency was compared, it was found that neutrophil ADCP elicited by V3 mAbs was significantly higher than V2i ADCP (Student's $t$ test; $p<$ 0.0001; Fig. 2g).

The ADCP Profile Exhibited by Neutrophils Is Unique When Compared to the Standard THP-1 Assay

The ADCP activity of the 7 HIV mAbs was also tested with THP-1 cells in a standard assay [16]. It was evident that the overall ADCP profile for THP-1 cells was different from that observed for neutrophils (Fig. 3). There were moderately statistically significant differences among the mean ADCP activities for each $\mathrm{mAb}$, as determined by one-way ANOVA. Significance was notably lower than observed for the neutrophil data $\left(\mathrm{F}_{6,7}=15\right.$, $p \leq 0.0011)$. Anti-V3 mAbs 3792 and 2557 did not display higher ADCP activity than the other $5 \mathrm{mAbs}$, and, in contrast to the results with neutrophils, anti-V3 mAb 2219 elicited the highest level of THP-1 cell ADCP. This activity was significantly higher than that of most other mAbs. Unlike the neutrophil ADCP profile, V2i mAb 2158 activity was also found to be significantly less potent than that of mAb 830A. When ADCP scores were grouped by specificity, no significant differences were noted between the 2 groups (data not shown).

ADCP scores generated in the neutrophil and THP-1 assays were also compared for each $\mathrm{mAb}$ by the twotailed Mann-Whitney U test. V3 mAbs 2557 and 3792 elicited significantly higher neutrophil than THP-1 ADCP scores. In contrast, anti-V3 mAb 2219 displayed 


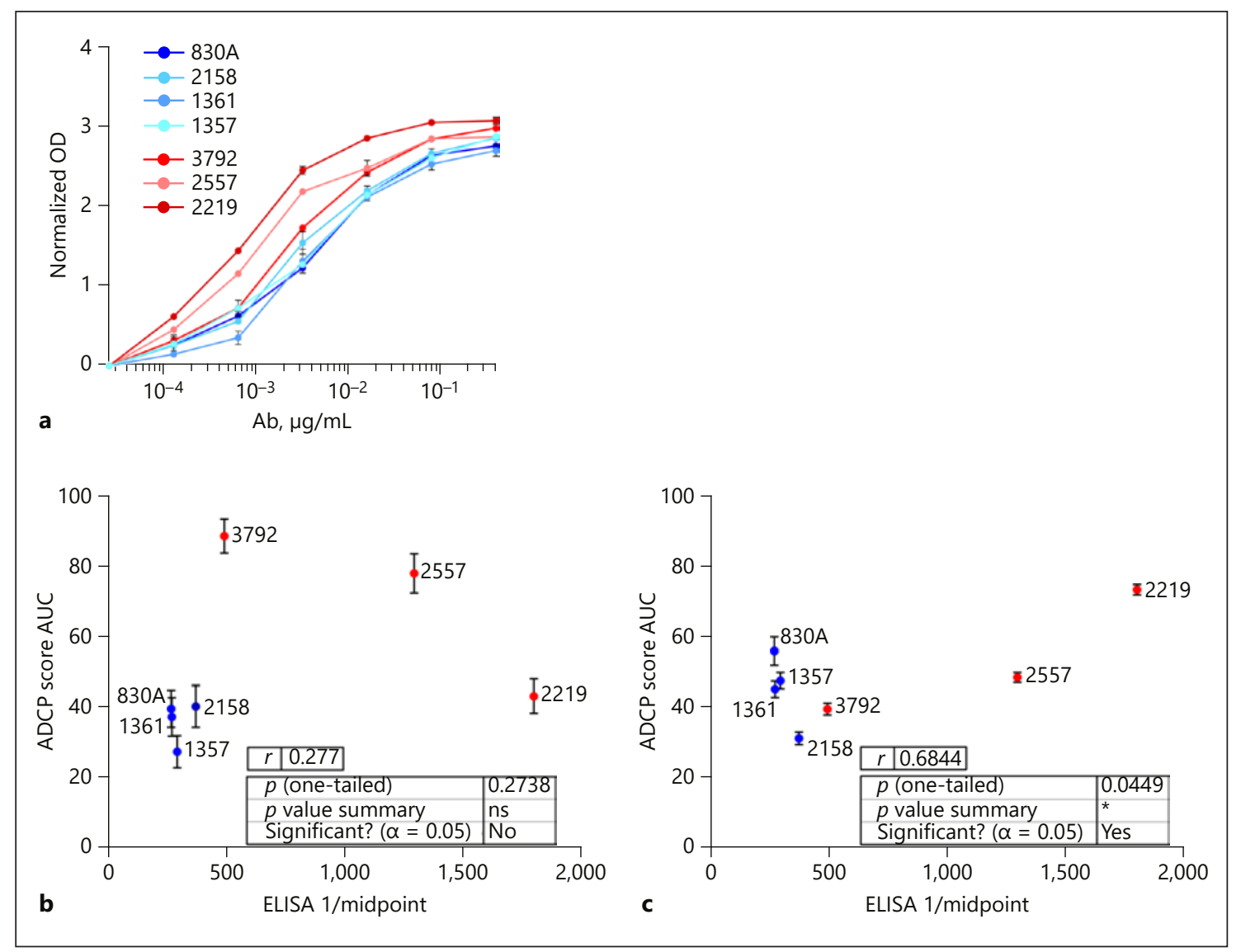

Fig. 5. ADCP by THP-1 cells correlates with ELISA midpoint titers to the same gp120 antigen. a ELISA was performed as described previously [38], with the same antigen used for ADCP assays $\left(\mathrm{gp} 120_{\mathrm{zm} 53}\right)$ coated to the plate. mAbs were titrated and OD values measured and normalized by subtraction of control mAb 3865 OD at each dilution $(n=3)$. Midpoint titers for each mAb were calculated in GraphPad Prism and compared to mean ADCP AUC values obtained for the neutrophil (b) and THP-1 (c) assays.

more potent ADCP activity in the THP-1 assay than in the neutrophil assay (Fig. 4). No significant differences in activity were observed when comparing the V2i mAbs in the 2 assays.

\section{ADCP by THP-1 Cells Correlates with ELISA Binding} Titers to the Same gp120 Antigen

In addition to the ADCP assays described above, a standard ELISA was performed using the same gp $120_{\mathrm{ZM} 53}$ antigen as was used for the ADCP assays. This protein was coated to the plate wells, and the same $7 \mathrm{mAbs}$ tested for ADCP were titrated to assess their relative binding affinity for gp120 (Fig. 5a), so as to determine the concurrence between $\mathrm{mAb}$ affinity and Fc-mediated function, and whether this relationship was similar for the THP-1 and neutrophil assays. The midpoint titers calculated from the ELISA titrations were compared to (AUC ADCP scores for each assay. For the neutrophil ADCP assay, no correlation existed between these 2 parameters (Fig. 5b), while the THP-1 ADCP scores did correlate with ELISA midpoint values for the mAbs tested (Pearson $r=0.68$; $p=0.045$; Fig. 5c).

Primary Blood Monocyte ADCP Exhibits High Donorto-Donor Variability and No Apparent Impact from $m A b$ Specificity

ADCP activity was also tested using primary blood monocytes. Cells were purified from 3 different donors, and the assay was developed, tested, and performed as described above for neutrophil ADCP. It was apparent that donor-to-donor variability strongly affected the ADCP activity observed (Fig. 6a-c). As such, few trends 


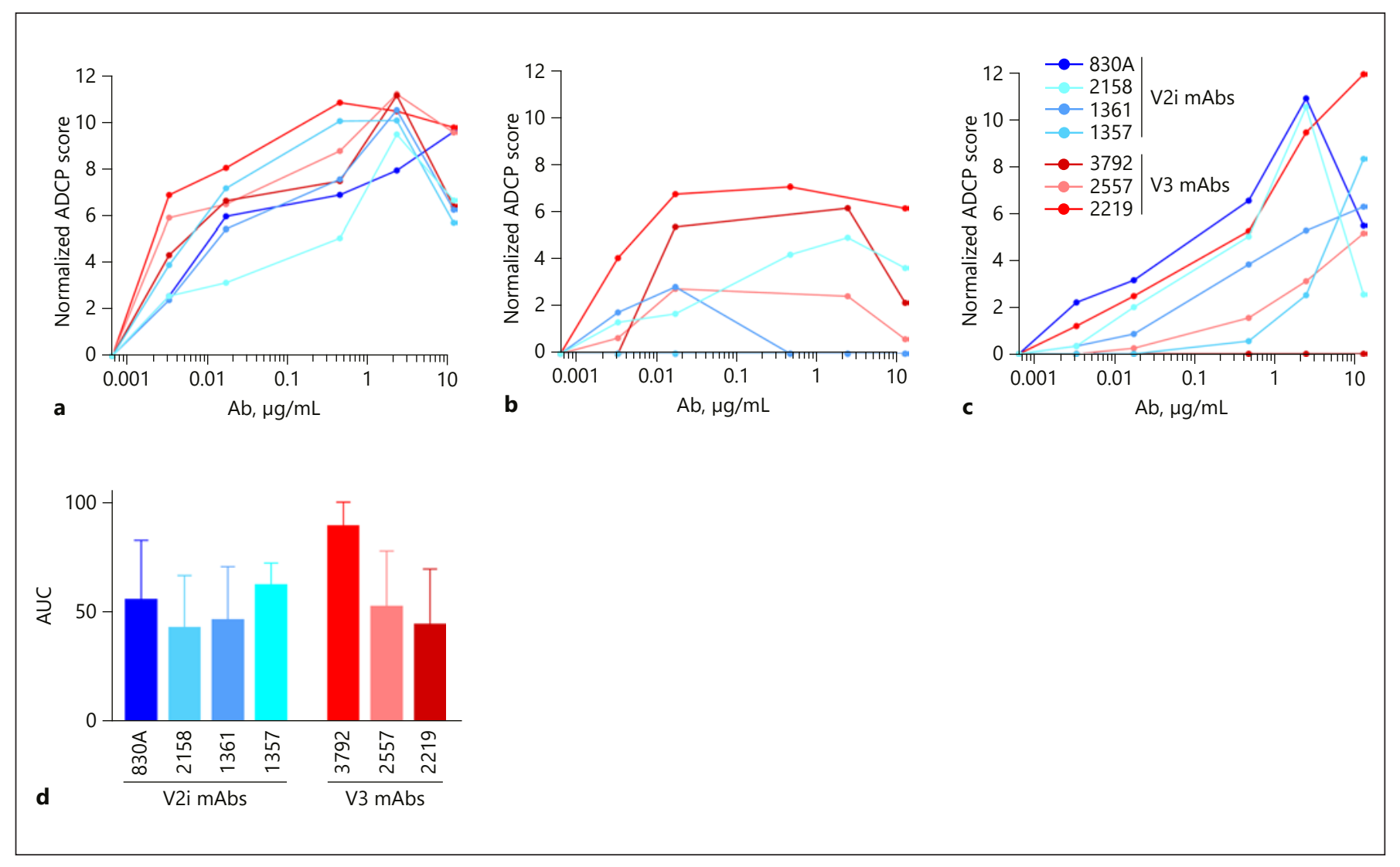

Fig. 6. ADCP profiles of primary blood monocytes exhibit significant donor-to-donor variation. a-c ADCP profile of monocytes obtained from 3 different donors. The assay was performed and scores calculated as above. d Mean AUC values with SEM were determined as above $(n=3)$.

were apparent regarding the relative potency of different $\mathrm{mAbs}$ in mediating ADCP. Mean AUC values were determined and compared by one-way ANOVA (Fig. 6d). No significant differences between the $\mathrm{mAbs}$ was found $\left(F_{6,14}=0.515, p=0.78\right)$. Similarly, ADCP scores grouped by specificity showed no significant differences between V2i and V3 groups, ADCP scores for each $m A b$ exhibited no significant differences from those obtained for the neutrophil or THP-1 assays, and no correlation with ELISA titers was found due to the high variance/error among the monocyte samples tested (data not shown).

\section{Discussion}

Abs that are unable to prevent viral entry per se but are capable of binding to the viral surface or viral proteins on the surface of infected cells can facilitate a variety of antiviral activities that ultimately contribute to viral clear- ance. Though the importance of $\mathrm{Fc} / \mathrm{FcR}$ functionality of Abs for protection from SIV, SHIV, and other pathogens was demonstrated previously, the analyses from the RV144 clinical trial provided the first evidence that Envspecific Abs without significant neutralizing capacity could mediate HIV vaccine efficacy, causing the field to seriously reconsider the importance of generating Abs with Fc-dependent functions [39-42].

Phagocytes are an essential and primitive component of the innate immune system common to all species throughout evolution [9]. ADCP has been demonstrated as necessary for the clearance of various viral infections and is an essential Fc/FcR-mediated phenomenon [18$20,43-47]$. With the development of the robust, flowcytometry-based ADCP assay by Ackerman et al. [16] using the THP-1 human monocyte cell line, the study of the capacity of HIV-specific mAbs and serum to mediate ADCP has become a standard assay, now cited in 75 different publications implementing these cells. What re- 
mains unclear is the relevance of ADCP as determined by means of the THP-1 cell line, and how ADCP activity measured with a cell line compares with that mediated by primary phagocytes. The ADCP activity of THP-1 cells has been previously compared to that of primary human monocytes; notable differences in response to IgA Abs were observed due to the virtual absence of FcRa on THP-1 cells compared to primary monocytes [17]. Little study has been done of neutrophil ADCP in the context of HIV, and no study to date has compared THP-1 cell ADCP and neutrophil ADCP. Given the FcR profile of neutrophils, long-established as unique [12, 48-51], and the fact that neutrophils are highly prevalent and active at all sites of HIV infection $[9,52]$, such an investigation is critical.

Here, we confirm that neutrophils can be used successfully in the standard ADCP assay, and that for target bead internalization to occur, neutrophil FcRs and functional actin dynamics are required. Five neutrophil donors were analyzed for ADCP elicited by HIV Env-specific mAbs, and although each donor did exhibit a unique profile, overall trends were quite evident. V3 mAbs elicited the highest neutrophil ADCP, and when mean ADCP scores were grouped according to $\mathrm{mAb}$ specificity, the $\mathrm{V} 3 \mathrm{mAbs}$ were shown to elicit significantly higher neutrophil ADCP than mAbs specific for the V2i epitope of gp120 (Fig. 2). The overall ADCP profile of the mAbs tested was different from that observed using THP-1 cells (Fig. 4). Using the standard THP-1 assay, no difference was observed between the V3 and V2i mAb groups (Fig. 3), and mAbs which were potent in the neutrophil assay were significantly less so in the THP-1 assay, and vice versa (Fig. 4). ADCP profiles observed using primary monocytes did not exhibit obvious trends among the $\mathrm{mAb}$ potencies. In fact, donor-to-donor variation among the 3 samples tested prohibited a meaningful comparison with the other datasets; however, it should be noted that this feature alone gives pause regarding the significance of THP-1 ADCP data in relation to the action of these Abs in vivo. Though outside the scope of this study, it is possible that testing a larger set of monocyte donors may have allowed trends in $\mathrm{mAb}$ activities to become apparent. Given that, compared to neutrophils, monocytes are comprised of a variety of lineages and subsets whose activities may be unique at each stage of maturation, and according to which compartment the cells are isolated from, considerably more study is needed to form a broader picture of primary monocyte ADCP.

Intriguingly, when ELISA binding titers for gp $120_{\mathrm{ZM} 53}$ were determined for the $\mathrm{mAb}$ panel, it was found that the midpoint titers correlated significantly with THP-1
ADCP but not with the assay using neutrophils. This suggests that the ADCP capacity of THP-1 cells is more dependent on Ab-binding affinity than is the case for neutrophils, while neutrophil ADCP capacity appeared more influenced by Ab specificity than THP-1 cells were.

The concept that the specificity of an Ab, i.e., the binding of the Fab region to its epitope, could propagate conformational changes across the molecule into the Fc domain to modulate Fc function has been extensively explored [5355]. For example, studies of Fc-mediated function against the influenza virus have shown that Ab specificity is crucial for the induction of these functions, and that not all virusbinding Abs will mediate the same $\mathrm{Fc} / \mathrm{FcR}$ activity [56]. In addition, a recent analysis of $\mathrm{HIV} \mathrm{mAb} 2 \mathrm{~F} 5$ binding to its gp41 target epitope showed clear evidence of allosteric interactions between epitope binding and the Fc domain [53]. Additionally, Abs with identical Fab (variable) regions can exhibit diverse antigen-binding affinities dependent solely on their Fc subclass/isotype, as demonstrated by SPR studies [57]. It is therefore highly plausible that the specificity of an HIV Ab might dictate its ability to induce Fc/FcR function, and that the induced activity may vary depending on the FcRs present on a given cell type. Clearly, an in-depth analysis is needed to examine the basis for differences in Fcmediated functions of various key cell types at the sites of HIV infection and beyond.

Neutrophils comprise the majority of leukocytes, have been demonstrated to be critical phagocytes of numerous pathogens, exhibit a unique FcR profile, and are found at all sites of HIV infection. This study strongly suggests that neutrophil $\mathrm{ADCP}$ in vivo may display different quantitative and qualitative differences from those observed using the THP-1 cell line. Given that neutrophils are relatively onerous to work with, due to their short half-life and the likelihood of overactivation and exhaustion, the use of a cell-line representative of neutrophil activity would be ideal. The human HL-60 cell line can be differentiated into neutrophil-like cells after culture with dimethyl sulfoxide (DMSO); however, FcR transcription and cell-surface levels are far lower and the profile quite different from those of true neutrophils $[58,59]$. Recently, ADCP assays using HIV-positive sera with both DMSO-treated HL-60 and primary neutrophils were compared, and ADCP scores were found to correlate well [59]. It is unknown if a more nuanced study using Abs of particular specificity would indicate the same. Our findings prompt the need for further study into the HIV Ab specificities and isotypes that best activate neutrophils and neutrophil-like cell lines, which will then inform the process of designing HIV vaccines to trigger effective Fc-mediated function. 


\section{Acknowledgements}

We thank Dr. Viviana Simon, Professor of Microbiology and Medicine at the Icahn School of Medicine, for IRB guidance.

\section{Disclosure Statement}

The authors declare that they have no conflicts of interests.

\section{Funding Sources}

The NIH/NIAID provided funding to all authors under grant No. P01 AI100151. In addition, S. Zolla-Pazner was supported by funds from the Department of Medicine, Division of Infectious Diseases, Icahn School of Medicine at Mount Sinai.

\section{References}

1 Haynes BF, Gilbert PB, McElrath MJ, ZollaPazner S, Tomaras GD, Alam SM, et al. Immune-correlates analysis of an $\mathrm{HIV}-1$ vaccine efficacy trial. N Engl J Med. 2012 Apr;366(14): 1275-86.

2 Tomaras GD, Ferrari G, Shen X, Alam SM, Liao HX, Pollara J, et al. Vaccine-induced plasma IgA specific for the $\mathrm{C} 1$ region of the HIV-1 envelope blocks binding and effector function of IgG. Proc Natl Acad Sci USA. 2013 May; 110(22):9019-24.

3 Pollara J, Bonsignori M, Moody MA, Liu P, Alam SM, Hwang KK, et al. HIV-1 vaccineinduced $\mathrm{C} 1$ and V2 Env-specific antibodies synergize for increased antiviral activities. J Virol. 2014 Jul;88(14):7715-26.

4 Tebo AE, Kremsner PG, Luty AJ. Plasmodium falciparum: a major role for IgG3 in antibody-dependent monocyte-mediated cellular inhibition of parasite growth in vitro. Exp Parasitol. 2001 May;98(1):20-8.

5 Florese RH, Demberg T, Xiao P, Kuller L, Larsen K, Summers LE, et al. Contribution of nonneutralizing vaccine-elicited antibody activities to improved protective efficacy in rhesus macaques immunized with Tat/Env compared with multigenic vaccines. J Immunol. 2009 Mar; 182(6):3718-27.

6 Hessell AJ, Hangartner L, Hunter M, Havenith CE, Beurskens FJ, Bakker JM, et al. Fc receptor but not complement binding is important in antibody protection against HIV. Nature. 2007 Sep;449(7158):101-4.

7 Ackerman M, Nimmerjahn F. Antibody Fc: Linking Adaptive and Innate Immunity. 1st ed. Tokyo: Elsevier; 2014.

8 Bruhns P, Iannascoli B, England P, Mancardi DA, Fernandez N, Jorieux S, et al. Specificity and affinity of human Fcgamma receptors and their polymorphic variants for human IgG subclasses. Blood. 2009 Apr;113(16): 3716-25.

9 Mayadas TN, Cullere X, Lowell CA. The multifaceted functions of neutrophils. Annu Rev Pathol. 2014;9(1):181-218.

10 Ramsuran V, Kulkarni H, He W, Mlisana K, Wright EJ, Werner L, et al. Duffy-null-associated low neutrophil counts influence HIV-1 susceptibility in high-risk South African black women. Clin Infect Dis. 2011 May;52(10): 1248-56.
11 Kourtis AP, Hudgens MG, Kayira D; BAN Study Team. Neutrophil count in African mothers and newborns and HIV transmission risk. N Engl J Med. 2012 Dec;367(23): $2260-2$.

12 Kimberly RP, Ahlstrom JW, Click ME, Edberg JC. The glycosyl phosphatidylinositollinked Fc gamma RIIIPMN mediates transmembrane signaling events distinct from $\mathrm{Fc}$ gamma RII. J Exp Med. 1990 Apr;171(4): 1239-55.

13 Rivas-Fuentes S, García-García E, NietoCastañeda G, Rosales C. Fcgamma receptors exhibit different phagocytosis potential in human neutrophils. Cell Immunol. 2010;263(1): 114-21.

14 Chen K, Nishi H, Travers R, Tsuboi N, Martinod K, Wagner DD, et al. Endocytosis of soluble immune complexes leads to their clearance by Fc $\gamma$ RIIIB but induces neutrophil extracellular traps via Fc $\gamma$ RIIA in vivo. Blood. 2012 Nov;120(22):4421-31.

15 Fortunati E, Kazemier KM, Grutters JC, Koenderman L, Van den Bosch J. Human neutrophils switch to an activated phenotype after homing to the lung irrespective of inflammatory disease. Clin Exp Immunol. 2009 Mar; 155(3):559-66.

16 Ackerman ME, Moldt B, Wyatt RT, Dugast AS, McAndrew E, Tsoukas S, et al. A robust, high-throughput assay to determine the phagocytic activity of clinical antibody samples. J Immunol Methods. 2011 Mar;366(1-2): 8-19.

17 Tay MZ, Liu P, Williams LD, McRaven MD, Sawant S, Gurley TC, et al. Antibody-Mediated Internalization of Infectious HIV-1 Virions Differs among Antibody Isotypes and Subclasses. PLoS Pathog. 2016 Aug; 12(8):e1005817.

18 Huber VC, Lynch JM, Bucher DJ, Le J, Metzger DW. Fc receptor-mediated phagocytosis makes a significant contribution to clearance of influenza virus infections. J Immunol. 2001 Jun;166(12):7381-8.

19 Chung KM, Thompson BS, Fremont DH, Diamond MS. Antibody recognition of cell surface-associated NS1 triggers Fc-gamma receptor-mediated phagocytosis and clearance of West Nile Virus-infected cells. J Virol. 2007 Sep;81(17):9551-5.
20 Yasui F, Kohara M, Kitabatake M, Nishiwaki T, Fujii H, Tateno C, et al. Phagocytic cells contribute to the antibody-mediated elimination of pulmonary-infected SARS coronavirus. Virology. 2014 Apr;454-455:157-68.

21 Gorny MK, Xu JY, Gianakakos V, Karwowska S, Williams C, Sheppard HW, et al. Production of site-selected neutralizing human monoclonal antibodies against the third variable domain of the human immunodeficiency virus type 1 envelope glycoprotein. Proc Nat Acad Sci USA. 1991 Apr;88(8):3238-42.

22 Scheid JF, Mouquet H, Feldhahn N, Seaman MS, Velinzon K, Pietzsch J, et al. Broad diversity of neutralizing antibodies isolated from memory B cells in HIV-infected individuals. Nature. 2009 Apr;458(7238):636-40.

23 Forthal DN, Landucci G, Gorny MK, ZollaPazner S, Robinson WE Jr. Functional activities of 20 human immunodeficiency virus type 1 (HIV-1)-specific human monoclonal antibodies. AIDS Res Hum Retroviruses. 1995 Sep;11(9):1095-9.

24 Andrabi R, Williams C, Wang XH, Li L, Choudhary AK, Wig N, et al. Cross-neutralizing activity of human anti-V3 monoclonal antibodies derived from non-B clade HIV-1 infected individuals. Virology. 2013 May; 439(2):81-8.

25 Gorny MK, Conley AJ, Karwowska S, Buchbinder A, Xu JY, Emini EA, et al. Neutralization of diverse human immunodeficiency virus type 1 variants by an anti-V3 human monoclonal antibody. J Virol. 1992 Dec; 66(12):7538-42.

26 Nyambi PN, Mbah HA, Burda S, Williams C, Gorny MK, Nádas A, et al. Conserved and exposed epitopes on intact, native, primary human immunodeficiency virus type 1 virions of group M. J Virol. 2000 Aug;74(15):7096-107.

27 Klein F, Gaebler C, Mouquet H, Sather DN, Lehmann C, Scheid JF, et al. Broad neutralization by a combination of antibodies recognizing the $\mathrm{CD} 4$ binding site and a new conformational epitope on the HIV-1 envelope protein. J Exp Med. 2012 Jul;209(8):1469-79.

28 Gorny MK, VanCott TC, Williams C, Revesz $\mathrm{K}$, Zolla-Pazner S. Effects of oligomerization on the epitopes of the human immunodeficiency virus type 1 envelope glycoproteins. Virology. 2000 Feb;267(2):220-8. 
29 Pinter A, Honnen WJ, He Y, Gorny MK, Zolla-Pazner S, Kayman SC. The V1/V2 domain of gp120 is a global regulator of the sensitivity of primary human immunodeficiency virus type 1 isolates to neutralization by antibodies commonly induced upon infection. J Virol. 2004 May;78(10):5205-15.

30 Spurrier B, Sampson J, Gorny MK, ZollaPazner S, Kong XP. Functional implications of the binding mode of a human conformation-dependent V2 monoclonal antibody against HIV. J Virol. 2014 Apr;88(8):4100-12.

31 Gorny MK, Revesz K, Williams C, Volsky B, Louder MK, Anyangwe CA, et al. The v3 loop is accessible on the surface of most human immunodeficiency virus type 1 primary isolates and serves as a neutralization epitope. J Virol. 2004 Mar;78(5):2394-404.

32 Gorny MK, Wang XH, Williams C, Volsky B, Revesz K, Witover B, et al. Preferential use of the VH5-51 gene segment by the human immune response to code for antibodies against the V3 domain of HIV-1. Mol Immunol. 2009 Feb;46(5):917-26.

33 Tiller T, Meffre E, Yurasov S, Tsuiji M, Nussenzweig MC, Wardemann H. Efficient generation of monoclonal antibodies from single human B cells by single cell RT-PCR and expression vector cloning. J Immunol Methods. 2008 Jan;329(1-2): 112-24.

34 Musich T, Li L, Liu L, Zolla-Pazner S, RobertGuroff M, Gorny MK. Monoclonal Antibodies Specific for the V2, V3, CD4-Binding Site, and gp41 of HIV-1 Mediate Phagocytosis in a Dose-Dependent Manner. J Virol. 2017 Mar; 91(8):e02325-16.

$35 \mathrm{Oh} \mathrm{H}$, Siano B, Diamond S. Neutrophil isolation protocol. J Vis Exp. 2008 Jul;17:pii 745.

36 Zolla-Pazner S, Powell R, Yahyaei S, Williams C, Jiang X, Li W, et al. Rationally Designed Vaccines Targeting the V2 Region of HIV-1 gp120 Induce a Focused, Cross-Clade-Reactive, Biologically Functional Antibody Response. J Virol. 2016 Nov;90(24):10993-1006.

37 Li X, Gibson AW, Kimberly RP. Human FcR polymorphism and disease. Curr Top Microbiol Immunol. 2014;382:275-302.

38 Recke A, Vidarsson G, Ludwig RJ, Freitag M, Möller S, Vonthein R, et al; German AIBD Genetic Study Group. Allelic and copy-number variations of $\mathrm{Fc} \gamma \mathrm{Rs}$ affect granulocyte function and susceptibility for autoimmune blistering diseases. J Autoimmun. 2015 Jul;61: $36-44$.
39 Jafarshad A, Dziegiel MH, Lundquist R, Nielsen LK, Singh S, Druilhe PL. A novel antibody-dependent cellular cytotoxicity mechanism involved in defense against malaria requires costimulation of monocytes FcgammaRII and FcgammaRIII. J Immunol. 2007 Mar;178(5):3099-106.

40 Xiao P, Zhao J, Patterson LJ, Brocca-Cofano E, Venzon D, Kozlowski PA, et al. Multiple vaccine-elicited nonneutralizing antienvelope antibody activities contribute to protective efficacy by reducing both acute and chronic viremia following simian/human immunodeficiency virus SHIV89.6P challenge in rhesus macaques. J Virol. 2010 Jul;84(14): 7161-73.

41 Gómez-Román VR, Patterson LJ, Venzon D, Liewehr D, Aldrich K, Florese R, et al. Vaccine-elicited antibodies mediate antibody-dependent cellular cytotoxicity correlated with significantly reduced acute viremia in rhesus macaques challenged with SIVmac251. J Immunol. 2005 Feb;174(4):2185-9.

42 Barouch DH, Alter G, Broge T, Linde C, Ackerman ME, Brown EP, et al. Protective efficacy of adenovirus/protein vaccines against SIV challenges in rhesus monkeys. Science. 2015 Jul;349(6245):320-4.

43 Fujimoto I, Pan J, Takizawa T, Nakanishi Y. Virus clearance through apoptosis-dependent phagocytosis of influenza A virus-infected cells by macrophages. J Virol. 2000 Apr; 74(7):3399-403.

44 Tumpey TM, García-Sastre A, Taubenberger JK, Palese P, Swayne DE, Pantin-Jackwood MJ, et al. Pathogenicity of influenza viruses with genes from the 1918 pandemic virus: functional roles of alveolar macrophages and neutrophils in limiting virus replication and mortality in mice. J Virol. 2005 Dec;79(23): 14933-44.

45 Fujisawa H. Neutrophils play an essential role in cooperation with antibody in both protection against and recovery from pulmonary infection with influenza virus in mice. J Virol. 2008 Mar;82(6):2772-83.

46 Zsengellér Z, Otake K, Hossain SA, Berclaz PY, Trapnell BC. Internalization of adenovirus by alveolar macrophages initiates early proinflammatory signaling during acute respiratory tract infection. J Virol. 2000 Oct; 74(20):9655-67.

47 Quattrocchi V, Langellotti C, Pappalardo JS, Olivera V, Di Giacomo S, van Rooijen N, et al. Role of macrophages in early protective immune responses induced by two vaccines against foot and mouth disease. Antiviral Res. 2011 Nov;92(2):262-70.
48 Selvaraj P, Rosse WF, Silber R, Springer TA The major Fc receptor in blood has a phosphatidylinositol anchor and is deficient in paroxysmal nocturnal haemoglobinuria. $\mathrm{Na}$ ture. 1988 Jun;333(6173):565-7.

49 Unkeless JC, Shen Z, Lin CW, DeBeus E. Function of human Fc gamma RIIA and $\mathrm{Fc}_{\mathrm{c}}$ gamma RIIIB. Semin Immunol. $1995 \mathrm{Feb}$; $7(1): 37-44$.

50 McKenzie SE, Schreiber AD. Fc gamma receptors in phagocytes. Curr Opin Hematol. 1998 Jan;5(1):16-21.

51 Tsuboi N, Asano K, Lauterbach M, Mayadas TN. Human neutrophil Fcgamma receptors initiate and play specialized nonredundant roles in antibody-mediated inflammatory diseases. Immunity. 2008 Jun;28(6):833-46.

52 Sips M, Krykbaeva M, Diefenbach TJ, Ghebremichael M, Bowman BA, Dugast AS, et al. Fc receptor-mediated phagocytosis in tissues as a potent mechanism for preventive and therapeutic HIV vaccine strategies. Mucosal Immunol. 2016 Nov;9(6):1584-95.

53 Crespillo S, Casares S, Mateo PL, ConejeroLara $F$. Thermodynamic analysis of the binding of $2 \mathrm{~F} 5$ ( $\mathrm{Fab}$ and immunoglobulin $\mathrm{G}$ forms) to its gp41 epitope reveals a strong influence of the immunoglobulin $\mathrm{Fc}$ region on affinity. J Biol Chem. 2014 Jan;289(2):594-9.

54 Hubbard MA, Thorkildson P, Kozel TR, AuCoin DP. Constant domains influence binding of mouse-human chimeric antibodies to the capsular polypeptide of Bacillus anthracis. Virulence. 2013 Aug;4(6):483-8.

55 Janda A, Bowen A, Greenspan NS, Casadevall A. Ig Constant Region Effects on Variable Region Structure and Function. Front Microbiol. 2016 Feb;7:22

56 He W, Tan GS, Mullarkey CE, Lee AJ, Lam MM, Krammer F, et al. Epitope specificity plays a critical role in regulating antibody-dependent cell-mediated cytotoxicity against influenza A virus. Proc Natl Acad Sci USA. 2016 Oct;113(42):11931-6.

57 Dodev TS, Bowen H, Shamji MH, Bax HJ, Beavil AJ, McDonnell JM, et al. Inhibition of allergen-dependent IgE activity by antibodies of the same specificity but different class. Allergy. 2015 Jun;70(6):720-4.

58 Rincón E, Rocha-Gregg BL, Collins SR. A map of gene expression in neutrophil-like cell lines. BMC Genomics. 2018 Aug;19(1):573.

59 Worley MJ, Fei K, Lopez-Denman AJ, Kelleher AD, Kent SJ, Chung AW. Neutrophils mediate HIV-specific antibody-dependent phagocytosis and ADCC. J Immunol Methods. 2018 Jun;457:41-52. 